\title{
Osteoporosis and type 2 diabetes mellitus: what do we know, and what we can do?
}

This article was published in the following Dove Press journal:

Patient Preference and Adherence

9 June 2012

Number of times this article has been viewed

\section{Shaymaa Abdalwahed \\ Abdulameer' \\ Syed Azhar Syed Sulaiman' \\ Mohamed Azmi Ahmad \\ Hassali ${ }^{\prime}$ \\ Karuppiah Subramaniam² \\ Mohanad Naji Sahib'}

'School of Pharmaceutical Sciences, Universiti Sains Malaysia, Penang, Malaysia; ${ }^{2}$ Diabetes Outpatient Clinic, Penang General Hospital, Penang, Malaysia
Correspondence: Shaymaa Abdalwahed Abdulameer

School of Pharmaceutical Sciences,

Universiti Sains Malaysia,

I 1800 Minden, Penang, Malaysia

Tel +6046035422

Fax +6046570017

Email xbm2004@yahoo.com
Abstract: Diabetes mellitus (DM) is a pandemic and chronic metabolic disorder with substantial morbidity and mortality. In addition, osteoporosis (OP) is a silent disease with a harmful impact on morbidity and mortality. Therefore, this systematic review focuses on the relationship between OP and type 2 diabetes mellitus (T2DM). Systematic reviews of full-length articles published in English from January 1950 to October 2010 were identified in PubMed and other available electronic databases on the Universiti Sains Malaysia Library Database. The following keywords were used for the search: T2DM, OP, bone mass, skeletal. Studies of more than 50 patients with T2DM were included. Forty-seven studies were identified. The majority of articles (26) showed increased bone mineral density (BMD), while 13 articles revealed decreased BMD; moreover, eight articles revealed normal or no difference in bone mass. There were conflicting results concerning the influence of T2DM on BMD in association with gender, glycemic control, and body mass index. However, patients with T2DM display an increased fracture risk despite a higher BMD, which is mainly attributable to the increased risk of falling. As a conclusion, screening, identification, and prevention of potential risk factors for OP in T2DM patients are crucial and important in terms of preserving a good quality of life in diabetic patients and decreasing the risk of fracture. Patients with T2DM may additionally benefit from early visual assessment, regular exercise to improve muscle strength and balance, and specific measures for preventing falls. Patient education about an adequate calcium and vitamin D intake and regular exercise is important for improving muscle strength and balance. Furthermore, adequate glycemic control and the prevention of diabetic complications are the starting point of therapy in diabetic patients.

Keywords: bone, diabetes, osteopenia, osteoporosis, skeletal

\section{Introduction}

Diabetes mellitus (DM) is a chronic metabolic disorder with substantial morbidity and mortality, characterized by the presence of hyperglycemia. ${ }^{1,2}$ Pharmacotherapy, continuing medical care, and education are crucial for preventing acute and chronic complications. On the other hand, osteoporosis (OP) is a painless weakening of the bones that constitutes an enormous socioeconomic crisis, with a harmful impact on morbidity and mortality. ${ }^{3,4}$ It leads to increased skeletal fragility and microarchitectural deterioration of bone tissue, causing a decrease in bone mineral density (BMD), bone quality, and strength. ${ }^{5,6}$ Osteoporosis can result in height loss, severe back pain, deformity, impairments in a person's ability to walk, disability, and even death. ${ }^{7,8}$

Moreover, OP has been considered to be a disorder of postmenopausal white women; several studies investigating BMD and fracture risk in women of different ethnicities 
have revealed conflicting evidence regarding osteoporosis risk. ${ }^{9}$ In addition, white women have higher hip fracture rates than black, Asian, and Hispanic women. ${ }^{10-12}$ Similarly, many results have indicated that Hispanic women are at higher risk for developing OP than non-Hispanic white women. ${ }^{13-15}$

Along with an increased risk of complications, including retinopathy, nephropathy, neuropathy, and cardiovascular events, there is strong evidence for reduced BMD in children, adolescents, and adults with type 1 diabetes mellitus (T1DM), ${ }^{16-23}$ which might reduce the peak bone mass attained and increase the risk of osteoporosis and its related complications in later life..$^{24,25}$ Though the relationship between T2DM and osteoporosis has been widely investigated, it remains controversial. Diabetes could influence bone through several mechanisms, some of which may have contradictory effects. Obesity, widespread in T2DM, is strongly associated with higher BMD, probably through mechanical loading and hormonal factors, including insulin, estrogen, and leptin. ${ }^{26-28}$ Hyperinsulinemia may promote bone formation. ${ }^{29}$ Therefore, low levels of insulin and the progression of T2DM may cause reductions in BMD. Higher glucose levels in the blood are known to interact with several proteins to generate a higher concentration of advanced glycation end-products (AGEs) in collagen that may reduce bone strength. ${ }^{30}$ Yamagishi et al hypothesized that AGEs in collagen may interact with bone to reduce bone strength, resulting in osteoporosis in patients with diabetes. ${ }^{31}$ Accumulated AGEs in the body may stimulate apoptosis of osteoblasts, thereby contributing to deficient bone formation. ${ }^{32}$ Another indirect effect of hyperglycemia is glycosuria, which causes hypercalciuria, leading to decreased levels of calcium in the body and poor bone quality, hastening bone loss. ${ }^{33,34}$ There is established evidence that low levels of vitamin D are not only associated with the incidence of DM but also that altered vitamin D metabolism leads to diabetic osteopenia. ${ }^{35,36}$

In addition, microvascular complications of diabetes lead to reduced blood flow to bone and may contribute to bone loss and fragility. ${ }^{37,38}$ Additional studies are required to determine whether DM is a leading cause of the development of osteoporosis or whether osteoporosis is aggravated by the presence of DM and should be considered as one of the long-term complications of diabetes. ${ }^{39-44}$ Thus, identifying and evaluating populations at increased risk of developing osteoporosis is critical in disease prevention and management.

In 1948, Albright and Reifenstein reported a loss of bone mass leading to osteoporosis in diabetic patients with poor glycemic control. ${ }^{45}$ Many clinical studies have reported that osteoporosis is one of the chronic complications associated with DM. These findings have received a great deal of attention and have been investigated by a number of researchers. ${ }^{46-48}$ Osteoporosis is a prevalent metabolic bone disease worldwide, ${ }^{49,50}$ and its occurrence in patients who have diabetes further increases their burden of disease. BMD is often used as an indication of susceptibility to osteoporosis. Bone mass is determined by the measure of peak bone mass, which attains a maximum in the second decade of life and starts to decrease after the third decade of life. ${ }^{51-53}$ Therefore, early BMD tests are very important. In order to define osteoporosis, a group of experts convened by the World Health Organization divided BMD T-scores into the three following categories: "normal (T-score of -1.0 or higher), osteopenia (T-score between -1.0 and -2.5 ), or osteoporosis (T-score $\leq-2.5) .{ }^{94}$ In addition to the diagnostic tools for osteoporosis (BMD test), Cummings et al suggested that it would be more sensible to focus on the risk of fracture based on a combination of factors, rather than solely relying on the diagnostic labels obtained from a T-score, since fracture risk factors are independent of BMD. ${ }^{55}$ For example, a woman who has a vertebral fracture has a fourfold increase in risk of another vertebral fracture regardless (or independent) of her BMD. ${ }^{56,57}$

Risk factors that predict hip fracture independently of BMD include age, personal history of fracture, parental history of hip fracture, ${ }^{58,59}$ current cigarette smoking, ${ }^{60-62}$ low body weight, ${ }^{63}$ poor health, low calcium intake, low level of vitamin D, alcoholism, inadequate physical activity, and use of (or plans to use) oral corticosteroids for longer than 3 months, ${ }^{64}$ or serious long-term conditions thought to increase fracture risk and the risk of falling, such as hyperthyroidism, hypogonadism, diabetes mellitus, rheumatoid arthritis, malabsorption, ${ }^{65,66}$ increased levels of markers of bone resorption, ${ }^{67}$ and very low serum levels of estradiol. ${ }^{68}$

\section{Methods}

Systematic reviews of full-length articles published in English from January 1950 to October 2010 were identified in PubMed, Medline, Inside Web, ISI Web of Knowledge, Science Direct, Springer Link, Ebsco Host, and other available electronic databases at Universiti Sains Malaysia Library. The following keywords were used in the search: type 2 diabetes mellitus, osteoporosis, bone, skeletal, BMD, dual X-ray absorptiometry (DXA), and quantitative ultrasound scan (QUS). More than 70 articles were identified, and those judged to be relevant by the authors were further evaluated. Clinical studies that included BMD measurements 
in patients with T2DM were extended to those using DXA and other methods. For studies that investigated BMD in T2DM, only studies that included more than 50 patients were reviewed.

\section{Results and discussion Key findings}

Forty-seven studies were identified: seven were from the US, six from Japan, four each from Turkey, Iran, and Italy, three from China, two each from Spain, the UK, Saudi Arabia, Kuwait, and Netherlands, and one each from Denmark, Greece, Sweden, Croatia, Canada, Norway, Egypt, Korea, and Finland. In general, most of the studies showed controversy over the effect of diabetes on bone mass in T2DM. The majority of articles (26) showed increased BMD, while 13 articles revealed decreased BMD; moreover, eight articles revealed normal or no difference bone mass, as shown in Table 1.

\section{Osteoporosis in diabetes mellitus type 2}

Diabetes has burdened the health-care system, which is already under strain due to other chronic diseases. Uncontrolled diabetes has led to an increase in the rate of complications, and thus has doubled the cost of treating these patients. ${ }^{69,70}$ It has long been known that the alterations in bone and mineral metabolism are clinically complicated in patients with DM. ${ }^{39,71}$ Although osteopenia is an established complication of T1DM, particularly in patients with poor control who have been treated with large doses of insulin, ${ }^{72}$ contradictory results have been found for patients with T2DM. ${ }^{73,74}$ In addition, there have been conflicting observations concerning the incidence of osteoporosis depending on differences in sex, age, and race or the methods used to detect the increase or decrease in BMD. ${ }^{33,75}$ In fact, a reduction in bone mineral content has been observed in both T1DM and T2DM patients. ${ }^{43,76}$

For patients with T2DM, some authors have reported an elevated $\mathrm{BMD},{ }^{75,77-81}$ other studies have reported a decreased $\mathrm{BMD},{ }^{33,43,74,76}$ and some have reported unaltered bone density, ${ }^{28,73,82}$; some cross-sectional studies have even found normal BMD ${ }^{83-85}$ Several mechanisms have been proposed for diabetes-related osteoporosis. These include both the comorbidities of diabetes and more direct pathophysiological effects of the disease itself. ${ }^{86-88}$

\section{Fractures and diabetes mellitus type 2}

The incidence of fracture was reported to be lower in T2DM patients compared to nondiabetic controls in some $e^{75,89}$ but not all studies. ${ }^{90,91}$ In addition, the relationship between fracture and T2DM is less clear, because many factors have an effect, such as an increase in BMD and different study designs, ages, body mass index (BMI), race, and gender, which all contribute to the conflicting results. In a study of nearly 1000 diabetic subjects, Heath and co-workers found decreased fracture rates in men and women with diabetes compared to the fracture incidence in the nondiabetic population, but they were unable to adjust for obesity, which is positively associated with T2DM and inversely associated with osteopenia. ${ }^{92}$ This was in contrast to the results of other studies, which was surprising given the increased fracture risk associated with T2DM..$^{93,94}$ A similar study found that whilst women with T2DM had a significant risk of hip fractures, this was much lower than for the women with T1DM..$^{95,96}$

On the other hand, T2DM was previously believed to be associated with normal to increased BMD, which may be considered as an osteoprotective effect. These reports were based on the concept of BMD alone and not from prospective controlled large trials. Moreover, BMD measurement in predicting osteoporotic fractures may be limited by two main factors: decreased bone quality (which cannot be measured by DXA) and a higher risk of falls. Bone quality changes may also be affected by microvascular events common in diabetes. ${ }^{38}$ Patients with T2DM generally have an increased risk of falling because of peripheral neuropathy, possible hypoglycemia, nocturia, and visual impairment. In addition, many type 2 diabetic patients are obese and sedentary; coordination and balance factors that are protective in falls may be absent. Thus, patients with generally larger body size and relatively high bone mass may have higher fracture rates. Therefore, normal BMD values may be misleading. A large prospective study of older women obtained from the Study of Osteoporotic Fractures confirmed that women with type 2 diabetes experience higher fracture rates in regions of the hip, humerus, and foot than do nondiabetic women. ${ }^{93}$

\section{Osteoporosis and gender}

Several studies found that people with T2DM have increased, normal, decreased, or no difference in bone mass compared to healthy control subjects. ${ }^{82-84,97}$ On the other hand, the problem of osteoporosis in men has been overlooked in the past. ${ }^{98}$ Although not as common as in women, hip and spine fractures in men are associated with higher morbidity and mortality than in women, ${ }^{99}$ and the prevalence of vertebral fractures in men is similar to or even higher than that in women. ${ }^{100,101}$ 


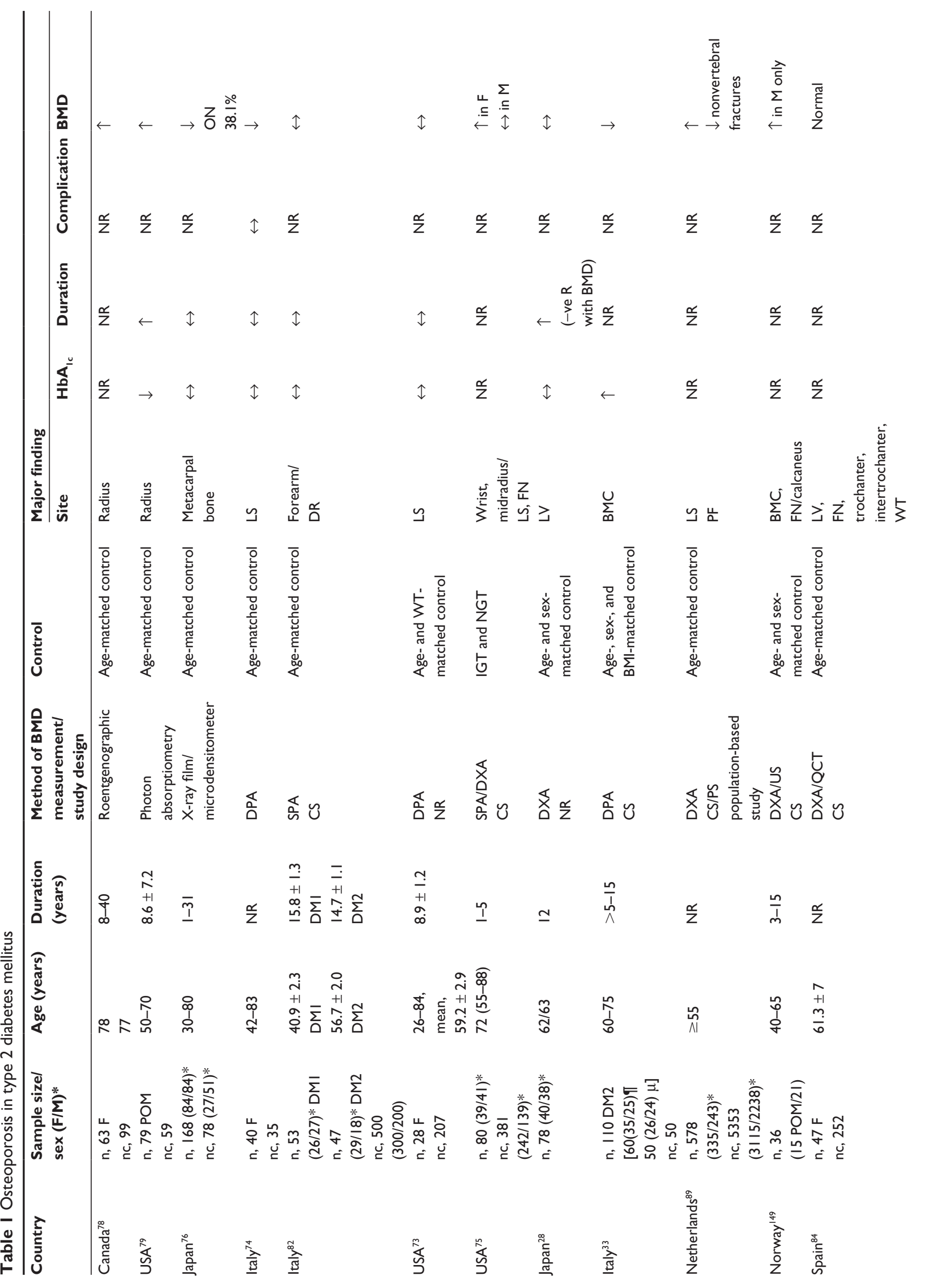




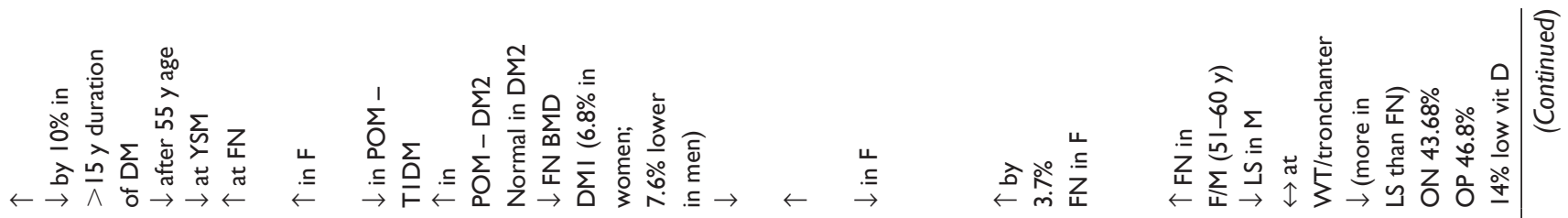

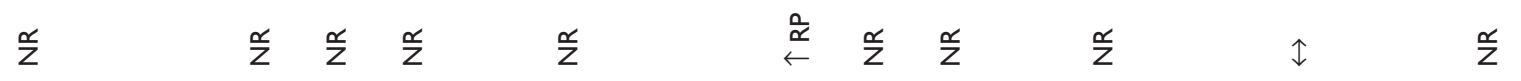

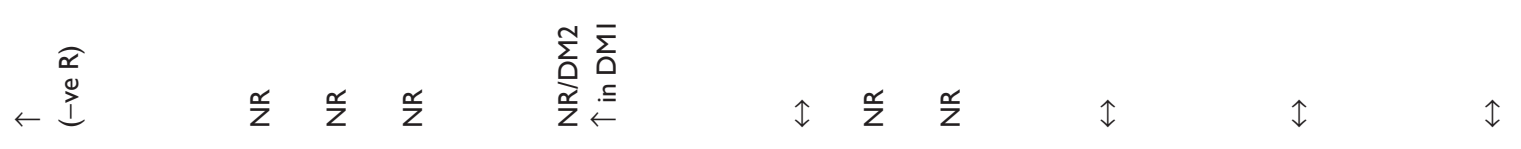

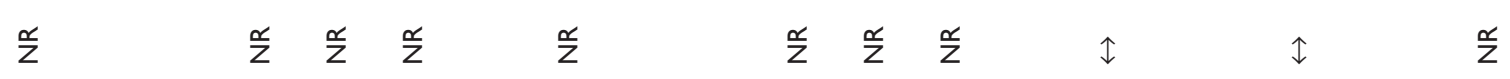

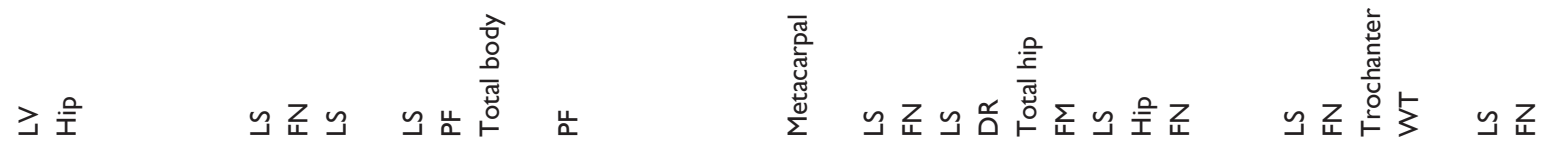

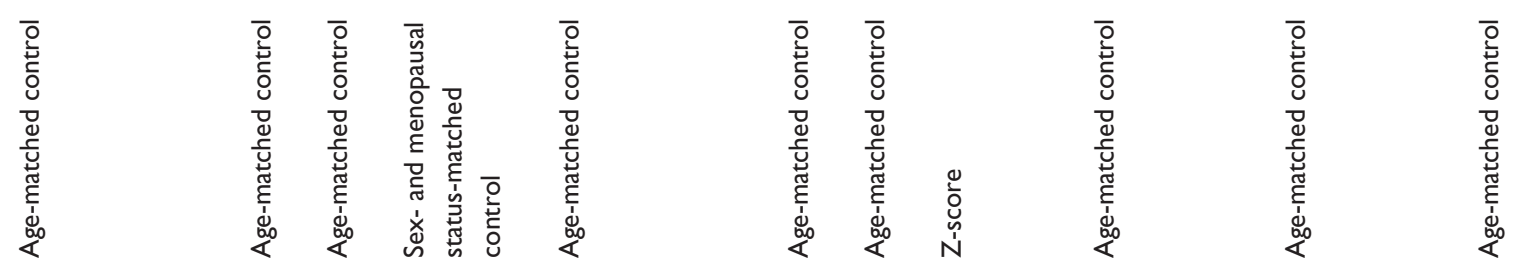

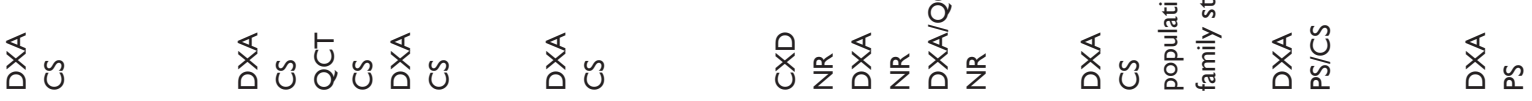

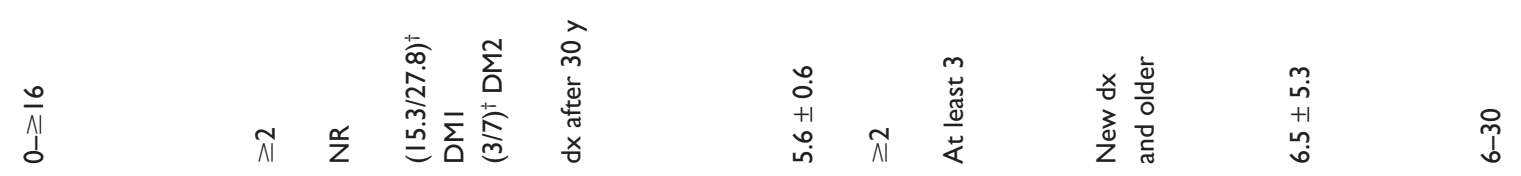

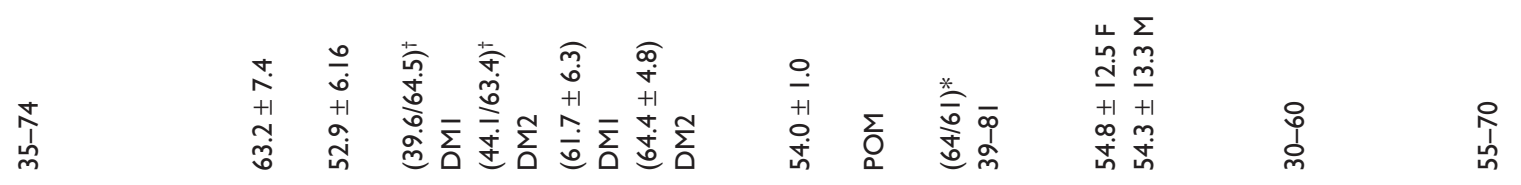

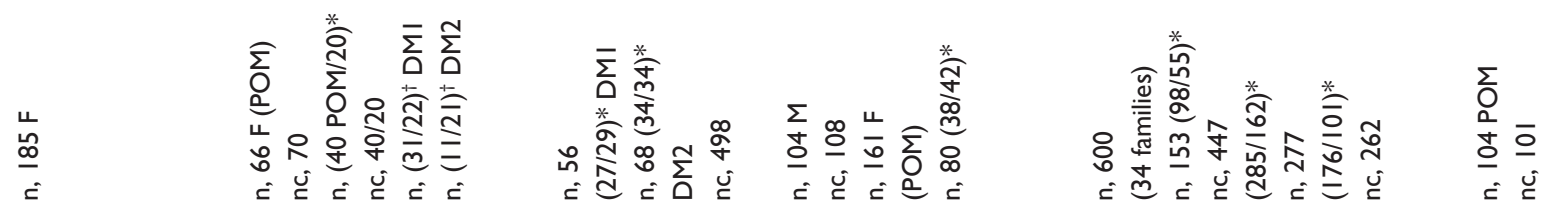

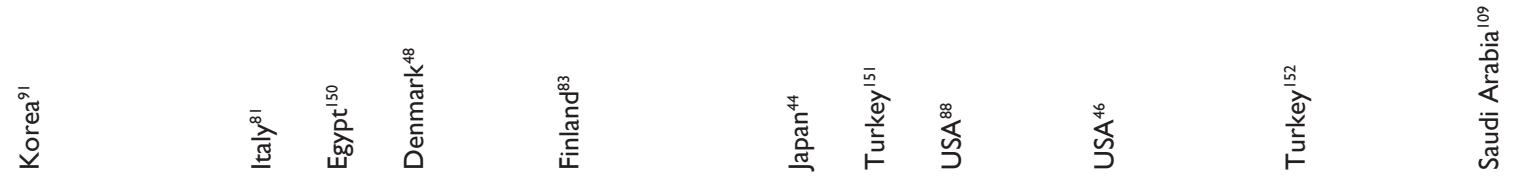




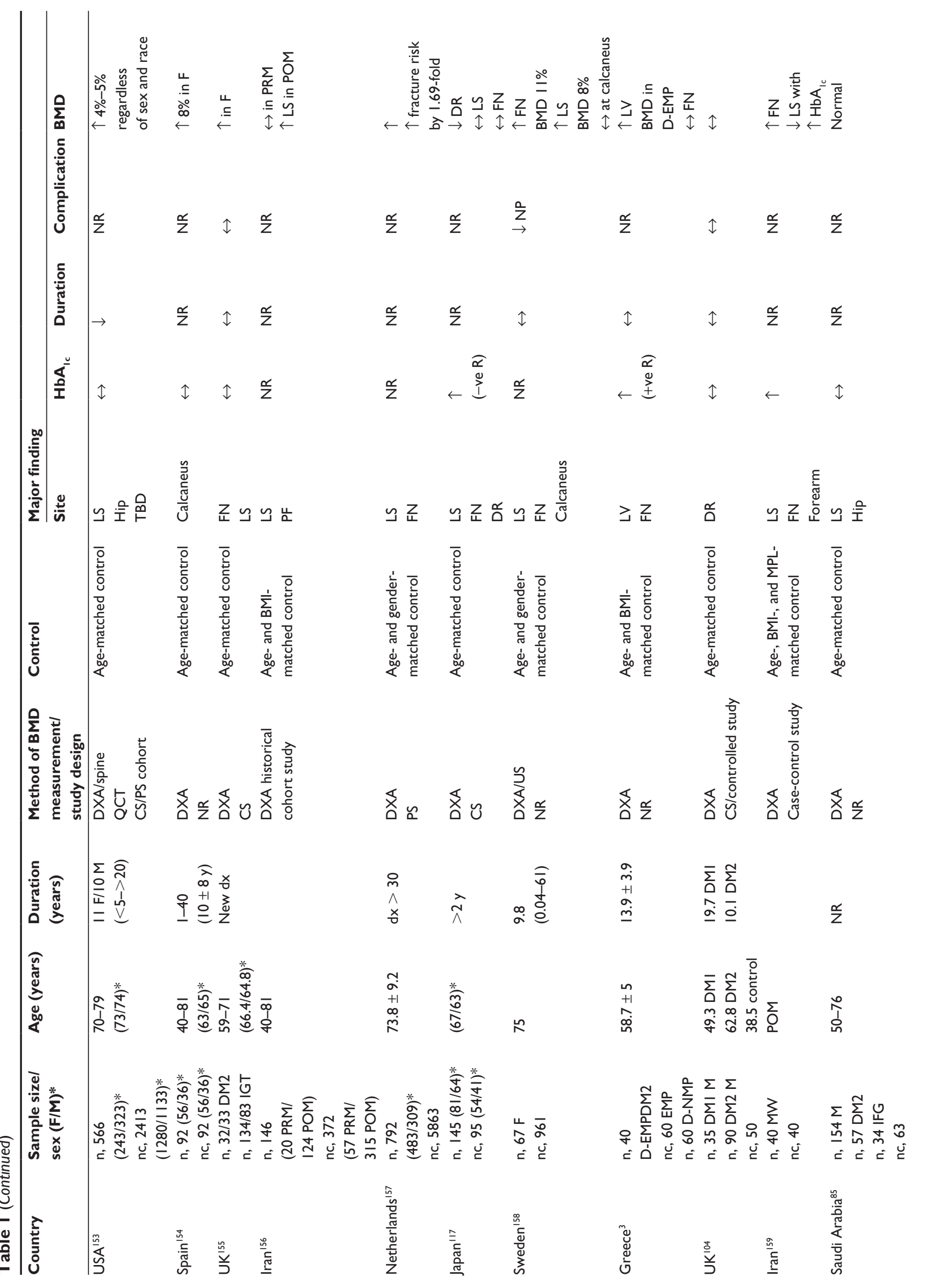




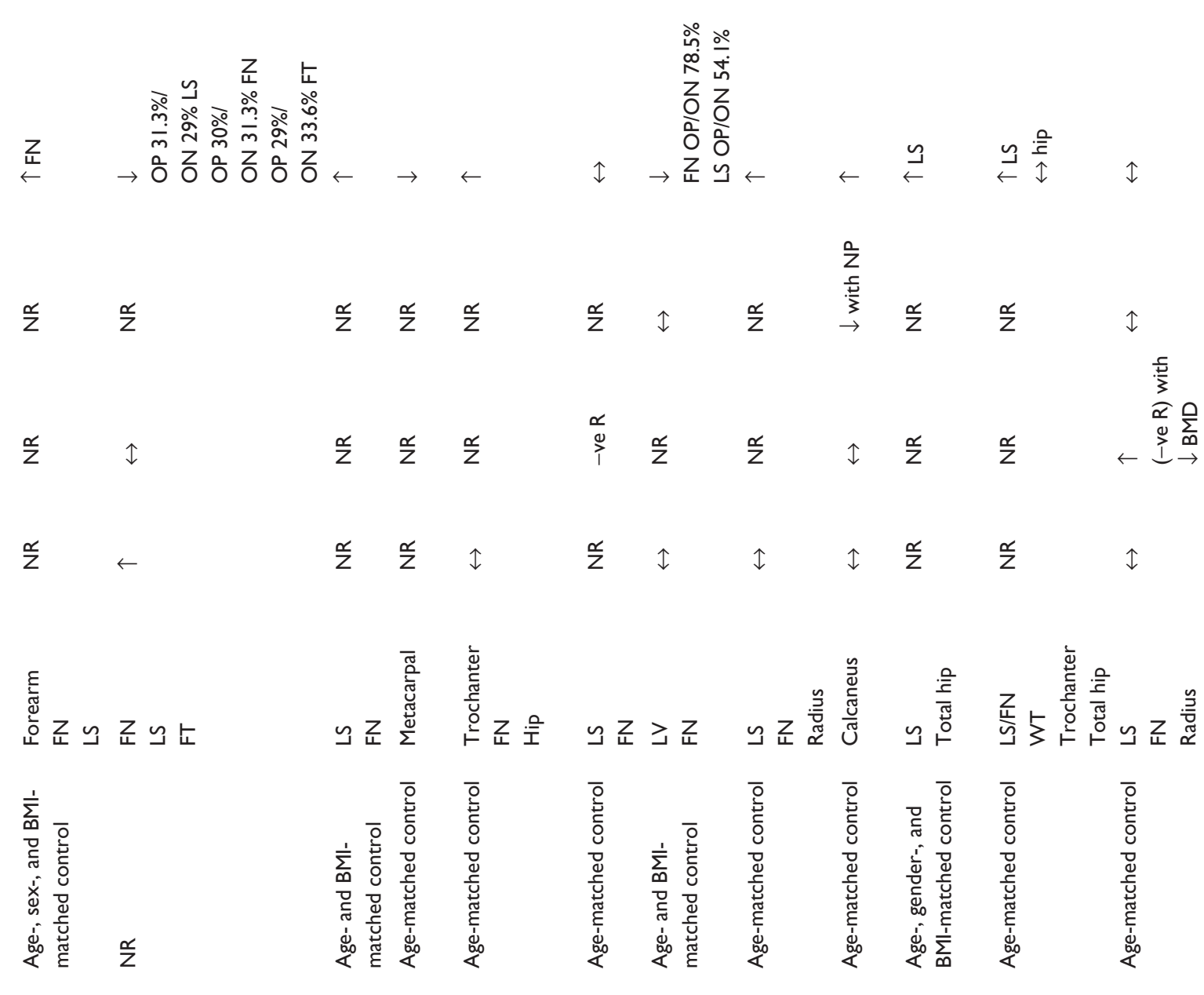




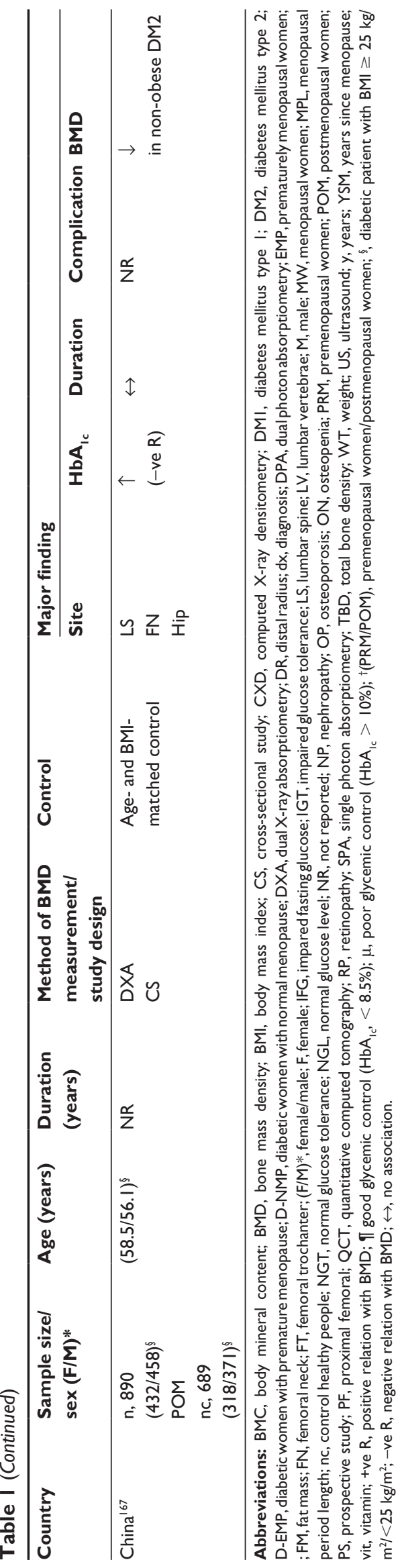

Three studies investigated the decrease in bone mass in men; two studies were performed using computed X-ray densitometry at the metacarpus bone in 151 and 104 male T2DM patients aged 55. ${ }^{44,102}$ The third study assessed BMD measured by DXA in 131 elderly T2DM males in China. The findings from this study also suggested that decreased BMD and poor glycemic control were correlated with osteoporosis. ${ }^{103}$ In contrast, Bridges et al assessed the BMD in 35 and 90 men with T1DM and T2DM, respectively, compared to 50 control subjects. This study found no difference between bone mass and diabetic status. In addition, no correlation was found between BMD and the glycosylated hemoglobin concentration, disease duration or the presence of microvascular or macrovascular complications in either of the diabetic groups. ${ }^{104}$

On the other hand, three studies reported a lower incidence of osteopenia and increased bone mass in older women with diabetes. In 1967, Meema and Meema reported a significantly increased cortical thickness of the radial bone in 63 elderly women with diabetes compared to 133 women without diabetes. This difference persisted after adjusting for body weight, and the authors postulated that diabetes was an "antiosteoporotic condition." 78

In 1985, Johnston and colleagues reported a significantly greater mid-radial bone mass in 79 postmenopausal women with $\mathrm{T} 2 \mathrm{DM}$ ( $68 \%$ of whom were being treated with insulin) compared to 59 in the control group. The calculated rate of bone loss was about half that expected and was not explained by obesity. ${ }^{79}$ In 1989 , Weinstock et al reported a nonsignificantly higher BMD in 28 T2DM women with mean age of 59 years compared to 207 age-matched volunteers. ${ }^{73}$ Thus, women with T2DM are not at an increased risk of diminished BMD, and may even be protected against bone loss. Relatively little attention has been paid to these remarkable findings. Since these studies were limited to women, sex differences were not described, and also the sample size was small. A similar finding was reported for 47 elderly T2DM women where the BMD was measured using two different methods (DXA and quantitative computed tomography), where no evidence was found to show that T2DM produces any change in bone metabolism or mass. ${ }^{84}$ Moreover, a population-based family study of Mexican Americans (600 subjects from 34 families) confirmed that diabetic women aged 55 years have a higher BMD compared to their nondiabetic counterparts. ${ }^{46}$ In addition, two studies assessed the association of T2DM with BMD in older patients (aged $\geq 55$ years), and both studies found an increase in BMD. ${ }^{75,89}$ In one population-based Rotterdam 
Study with a sample size of 5931, it was shown that both men and women with T2DM had an increased BMD, and that in women this was associated with a lower frequency of nonvertebral fractures. ${ }^{89}$ A similar finding related to increased BMD found in white diabetic women, whereas no differences in bone density according to diabetic status were observed in men, and the sex differences were explained by the greater androgenicity reported in women with hyperglycemic and hyperinsulinemic conditions. ${ }^{75}$

On the other hand, menopause is one of the most important risk factors for osteoporosis in women and is characterized by rapid bone loss in newly postmenopausal women. The loss of BMD is accelerated after the cessation of ovarian secretions, ${ }^{105,106}$ and estrogen deficiency is an important factor causing osteoclast activation. ${ }^{107}$ In our survey of the scientific literature related to the association between T2DM and bone mass, we identified 16 studies out of 47 that assessed bone mass in postmenopausal T2DM; the majority (13) of studies showed increased BMD and lower osteoporosis risk, whereas two studies showed decreased $\mathrm{BMD}^{108,109}$ and one study showed no difference in BMD when compared with normal subjects, ${ }^{110}$ as shown in Table 1.

\section{Osteoporosis and glycemic control}

Most of the studies were performed on T2DM patients under fairly controlled and stable conditions; in one of these studies, the mean glycosylated hemoglobin was $6.7 \% .^{75}$ Therefore, it is as yet unknown whether changes in glycemic control influence bone turnover in T2DM patients, although some papers have reported that BMD decreased more severely in patients with poorly controlled type 2 diabetes. ${ }^{33,111}$ In 1997 , one study assessed BMD before and after glycemic control for 3 weeks in 78 patients with poorly controlled T2DM (age 28-73 years) with an initial glycosylated hemoglobin level of more than $8 \%$, and found that metabolic improvements in poorly controlled T2DM decreased bone loss within a short period. Thus, glycemic control might protect T2DM patients from bone loss. ${ }^{12}$ On the other hand, some studies have reported that insulin level has a vital effect on bone mass. ${ }^{113-117}$ Japanese T2DMs have the clinical feature of low insulin secretion, which may predispose them to the risk of lower BMD. ${ }^{118,119}$ In 2005, Majima et al assessed the association between T2DM, BMD, metabolic control, and insulin-secretion capacity in 145 elderly Japanese diabetic patients compared to 95 subjects in the control group who were of a similar age. This study indicated that there was loss in cortical bone and positive correlation between the levels of insulin secretion and BMD at different sites (lumbar spine, femoral neck, distal radius); in addition, maintaining good metabolic control was key in preventing bone loss in T2DM. ${ }^{117}$ In contrast, Oz et al, in 2006, found an association between T2DM and higher BMD in 52 diabetic men and women aged 41-64 years compared to 48 nondiabetic control subjects. These findings suggest that although bone mass formation is lower in T2DM, diabetic patients are not susceptible to bone resorption. This low bone turnover can slow the rate of bone loss and cause a higher BMD than would be expected for a certain age. ${ }^{120}$

\section{Osteoporosis and body mass index}

Another important factor that affects BMD and confuses findings is the BMI, in addition to heredity, nutritional dietary customs, height, and lean mass. ${ }^{121,122}$ A low BMI is associated with decreased BMD, the increased possibility of osteoporosis, and the risk of fracture. ${ }^{123}$ A meta-analysis demonstrated that BMI is also an important predictor of BMD in T2DM. ${ }^{124}$ Overweight and obesity are believed to be protective factors of BMD. ${ }^{125,126}$ Compared with Caucasian populations, diabetic women in Asia are relatively shorter, a lower percentage are overweight, and they have a lower insulin sensitivity. ${ }^{127,128}$ Furthermore, BMI is a powerful and modifiable risk factor for both DM and OP. ${ }^{129,130}$ However, the impact of BMI with racial/ethnic disparities in overweight and obesity (measured by BMI) is well documented in many studies. ${ }^{131,132}$ BMI disparities are more pronounced and consistent among women, ${ }^{133,134}$ age, ${ }^{135}$ education, ${ }^{136}$ existence of morbid conditions, ${ }^{137}$ and marital status. ${ }^{136}$ Seo and Torabi examined the effect of race/ethnicity on BMI among US adults by gender, adjusting the effects of age, education, serious morbidity, and marital status. There was no evidence of decrease in the prevalence of overweight or BMI and diabetes among US adults. ${ }^{138}$

However, in Western countries, a BMI $\geq 27 \mathrm{~kg} / \mathrm{m}^{2}$ is often used to define obesity. Using this definition, $33 \%$ of US adults are considered to be overweight, ${ }^{139}$ while in Hong Kong Chinese of working age, only $11.6 \%$ have a $\mathrm{BMI} \geq 27 \mathrm{~kg} / \mathrm{m}^{2} \cdot{ }^{140}$ If BMI $\geq 30 \mathrm{~kg} / \mathrm{m}^{2}$ is used to define obesity, $8 \%-15 \%$ of Caucasians ${ }^{141,142}$ but only $2.2 \%-4.8 \%$ of Hong Kong Chinese will be considered to be obese. ${ }^{140}$ Similarly, the mean BMI in UK subjects is $26.0 \mathrm{~kg} / \mathrm{m}^{2}$ for men and $26.3 \mathrm{~kg} / \mathrm{m}^{2}$ for women. ${ }^{143}$ This is compared to $23.4 \mathrm{~kg} / \mathrm{m}^{2}$ and $23.3 \mathrm{~kg} / \mathrm{m}^{2}$ in Hong Kong Chinese men and women, respectively. In addition, Asians, although mean BMI is lower, have a higher percentage body fat and more upper-body subcutaneous fat. ${ }^{127}$ A recent study of more than 13,000 Chinese men and women 
with significantly lower mean BMI $\left(21 \mathrm{~kg} / \mathrm{m}^{2}\right)$ found the percentage body fat was inversely related to BMD as measured by DXA at the spine, hip, and total body. ${ }^{144}$ In a meta-analysis that included data for three Asian groups, Deurenberg et al found that the percentage body fat was higher than predicted at low BMI levels for Chinese. Body fat was underestimated across all BMI levels for Thais and Indonesians. ${ }^{145}$ In a similar study of women in Hawaii, Novotny et al found that Asian women had a greater percentage of body fat than did white women with the same BMI. ${ }^{146}$ The limited data concerning the correlation between BMI and adiposity suggest that health effects of BMI may differ as US-born Asian Americans are significantly more likely to be obese or overweight than the foreign-born Asian Americans. ${ }^{127}$ These conflicting results suggest a complex relationship between fat mass and bone mass is likely depending on the patient's age, sex and ethnicity. ${ }^{147}$ To date, relatively few studies have examined this relationship. ${ }^{148}$

\section{Conclusion}

With progressive aging of the population, there will be a huge increase in the prevalence of osteoporosis, which is considered to be one of the most common public health problems in the world. However, the impact of diabetes disease on osteoporosis has not yet been carefully considered. Therefore, there is a need for further longitudinal studies, including the incidence and risk factors for osteoporotic fractures. In clinical routine, the extent of diagnostic and therapeutic activities in patients with T2DM in respect to generalized bone disease or diabetic osteopenia should be based on individual conditions and risk profile for osteoporosis. In addition, osteoprotective behavior must be assessed, as low educational levels about OP may put those populations at high risk of fractures. Therefore, patient education needs to highlight that weight-bearing exercise and consuming calcium-rich foods not only prevent osteoporosis but also can decrease BMI, reduce blood pressure, and improve lipid and diabetic control, which are often significant risk comorbidities in diabetic patients. Therefore, the routine screening of risk factors and patient education about bone density evaluation are important and should be recommended to all diabetic patients. Also, all patients with diabetes, and particularly those with high risk of fractures, should be given general information regarding proper home-safety measures to reduce risk of falling, including the wearing of hip protectors, especially in the elderly. Future studies need to be prospective, controlled with large sample sizes, and include evaluations of bone quality at different sites (not just bone size), BMI, the duration of diabetes, race, glycemic control, fractures, complications, and BMD, in order to identify the possible relationship between diabetes and osteoporosis.

\section{Acknowledgment}

SA Abdulameer gratefully acknowledges the Universiti Sains Malaysia, Penang, Malaysia, for granting her the USM Postgraduate Student Fellowship.

\section{Disclosure}

The authors report no conflicts of interest in this work.

\section{References}

1. Rodbard HW, Blonde L, Braithwaite SS, et al. American Association of Clinical Endocrinologists medical guidelines for clinical practice for the management of diabetes mellitus. Endocr Pract. 2007; 13:1-68.

2. Roglic G, Unwin N, Bennett PH, et al. The burden of mortality attributable to diabetes. Diabetes Care. 2005;28(9):2130-2135.

3. Hadjidakis D, Mylonakis A, Sfakianakis M, Raptis A, Raptis S. Diabetes and premature menopause: is their co-existence detrimental to the skeleton? Eur J Endocrinol. 2005;152(3):437-442.

4. Reyes B, Moreno O. Prevalence of osteopenia and osteoporosis in postmenopausal women. Aten Primaria. 2005;35(7):342-347. Spanish.

5. Cooper C, Melton L 3rd. Epidemiology of osteoporosis. Trends Endocrinol Metab. 1992;3(6):224-229.

6. New S. Bone health: the role of micronutrients. Br Med Bull. 1999;55(3): 619-633.

7. Heinemann D. Osteoporosis. An overview of the National Osteoporosis Foundation clinical practice guide. Geriatrics. 2000;55(5):31-36.

8. Salkeld G, Cameron I, Cumming R, et al. Quality of life related to fear of falling and hip fracture in older women: a time trade off study. $B M J$. 2000;320(7231):341-346.

9. Babbar R, Handa A, Lo C, et al. Bone health of immigrant Chinese women living in New York City. J Community Health. 2006;31(1): $7-23$.

10. Pollitzer WS, Anderson JJ. Ethnic and genetic differences in bone mass: a review with a hereditary vs environmental perspective. Am J Clin Nutr. 1989;50(6):1244-1259.

11. Silverman SL, Madison RE. Decreased incidence of hip fracture in Hispanics, Asians, and blacks: California Hospital Discharge Data. Am J Public Health. 1988;78(11):1482-1483.

12. Ross PD, Norimatsu H, Davis JW, et al. A comparison of hip fracture incidence among native Japanese, Japanese Americans, and American Caucasians. Am J Epidemiol. 1991;133(8):801-809.

13. Siris ES, Chen YT, Abbott TA, et al. Bone mineral density thresholds for pharmacological intervention to prevent fractures. Arch Intern Med. 2004;164(10):1108-1112.

14. Siris E, Miller P, Barrett-Connor E, Abbott T, Sherwood L, Berger M. Design of NORA, the National Osteoporosis Risk Assessment Program: a longitudinal US registry of postmenopausal women. Osteoporos Int. 1998;8:S62-S69.

15. Siris ES, Miller PD, Barrett-Connor E, et al. Identification and fracture outcomes of undiagnosed low bone mineral density in postmenopausal women. JAMA. 2001;286(22):2815-2822.

16. Lettgen B, Hauffa B, Möhlmann C, Jeken C, Reiners C. Bone mineral density in children and adolescents with juvenile diabetes: selective measurement of bone mineral density of trabecular and cortical bone using peripheral quantitative computed tomography. Horm Res. 1995; 43(5):173-175. 
17. Gunczler P, Lanes R, Paz-Martinez V, et al. Decreased lumbar spine bone mass and low bone turnover in children and adolescents with insulin dependent diabetes mellitus followed longitudinally. $J$ Pediatr Endocrinol Metab. 1998;11(3):413-419.

18. Ersoy B, Gök en D, Darcan S, Mavi E, Öztürk C. Evaluation of bone mineral density in children with diabetes mellitus. Indian J Pediatr. 1999;66(3):375-379

19. Hough F. Alterations of bone and mineral metabolism in diabetes mellitus. II: Clinical studies in 206 patients with type I diabetes mellitus SAMJ S Afr Med J. 1987;72(2):120-126.

20. Leon M, Larrodera L, Lledo G, Hawkins F. Study of bone loss in diabetes mellitus type 1. Diabetes Res Clin Pract. 1989;6(3):237-242.

21. Wiske P, Wentworth S, Norton J Jr, Epstein S, Johnston C Jr. Evaluation of bone mass and growth in young diabetics. Metabolism. 1982;31(8): 848-854.

22. Auwerx J, Dequeker J, Bouillon R, Geusens P, Nijs J. Mineral metabolism and bone mass at peripheral and axial skeleton in diabetes mellitus. Diabetes. 1988;37(1):8-12.

23. Forst T, Beyer J, Pfützner A, et al. Peripheral osteopenia in adult patients with insulin-dependent diabetes mellitus. Diabet Med. 1995;12(10) 874-879.

24. Nevitt M, Johnell O, Black D, Ensrud K, Genant H, Cummings S. Bone mineral density predicts non-spine fractures in very elderly women. Osteoporos Int. 1994;4(6):325-331.

25. Melton L 3rd, Atkinson E, O'Fallon W, Wahner H, Riggs B. Long-term fracture prediction by bone mineral assessed at different skeletal sites. J Bone Miner Res. 1993;8(10):1227-1233.

26. Felson DT, Zhang Y, Hannan MT, Anderson JJ. Effects of weight and body mass index on bone mineral density in men and women: the Framingham study. J Bone Miner Res. 1993;8(5):567-573.

27. Thomas T, Burguera B, Melton LJ, et al. Role of serum leptin, insulin, and estrogen levels as potential mediators of the relationship between fat mass and bone mineral density in men versus women. Bone. 2001; 29(2):114-120.

28. Wakasugi M, Wakao R, Tawata M, Gan N, Koizumi K, Onaya T. Bone mineral density measured by dual energy $\mathrm{X}$-ray absorptiometry in patients with non-insulin-dependent diabetes mellitus. Bone. 1993; 14(1):29-33.

29. Reid I, Evans M, Cooper G, Ames RW, Stapleton J. Circulating insulin levels are related to bone density in normal postmenopausal women. Am J Physiol Endocrinol Metab. 1993;265(4):E655-E659.

30. Paul R, Bailey A. Glycation of collagen: the basis of its central role in the late complications of ageing and diabetes. Int J Biochem Cell Biol. 1996;28(12):1297-1310.

31. Yamagishi S, Nakamura K, Inoue H. Possible participation of advanced glycation end products in the pathogenesis of osteoporosis in diabetic patients. Med Hypotheses. 2005;65(6):1013-1015.

32. Alikhani M, Alikhani Z, Boyd C, et al. Advanced glycation end products stimulate osteoblast apoptosis via the MAP kinase and cytosolic apoptotic pathways. Bone. 2007;40(2):345-353

33. Gregorio F, Cristallini S, Santeusanio F, Filipponi P, Fumelli P. Osteopenia associated with non-insulin-dependent diabetes mellitus: what are the causes? Diabetes Res Clin Pract. 1994;23(1):43-54.

34. Raskin P, Stevenson MRM, Barilla DE, Pak CYC. The hypercalciuria of diabetes mellitus: its amelioration with insulin. Clin Endocrinol (Oxf). 1978;9(4):329-335.

35. Ishida H, Seino Y, Matsukura S, et al. Diabetic osteopenia and circulating levels of vitamin D metabolites in type 2 (noninsulindependent) diabetes. Metabolism. 1985;34(9):797-801.

36. Pittas AG, Lau J, Hu FB, Dawson-Hughes B. The role of vitamin D and calcium in type 2 diabetes. a systematic review and meta-analysis. J Clin Endocrinol Metab. 2007;92(6):2017-2029.

37. Wientroub S, Eisenberg D, Tardiman R, Weissman S, Salama R. Is diabetic osteoporosis due to microangiopathy? Lancet. 1980; 2(8201):983.

38. Vogt MT, Cauley JA, Kuller LH, Nevitt MC. Bone mineral density and blood flow to the lower extremities: the study of osteoporotic fractures. J Bone Miner Res. 1997;12(2):283-289.
39. Piepkorn B, Kann P, Forst T, Andreas J, Pfutzner A, Beyer J. Bone mineral density and bone metabolism in diabetes mellitus. Horm Metab Res. 1997;29(11):584-591.

40. Leidig-Bruckner G, Ziegler R. Diabetes mellitus: a risk for osteoporosis? Exp Clin Endocrinol Diabetes. 2001;109:493-514.

41. Schwartz A. Diabetes mellitus: does it affect bone? Calcif Tissue Int 2003;73(6):515-519.

42. Thrailkill K, Lumpkin Jr C, Bunn R, Kemp S, Fowlkes J. Is insulin an anabolic agent in bone? Dissecting the diabetic bone for clues. Am J Physiol Endocrinol Metab. 2005;289(5):E735-E745.

43. Levin M, Boisseau V, Avioli L. Effects of diabetes mellitus on bone mass in juvenile and adult-onset diabetes. N Engl J Med. 1976;294(5): 241-245.

44. Suzuki K, Sugimoto C, Takizawa M, et al. Correlations between bone mineral density and circulating bone metabolic markers in diabetic patients. Diabetes Res Clin Pract. 2000;48(3):185-191.

45. Albright F, Reifenstein E. Bone development in diabetic children: a roentgen study. Am J Med Sci. 1948;174:313-319.

46. Kao WH, Kammerer C, Schneider J, Bauer R, Mitchell B. Type 2 diabetes is associated with increased bone mineral density in MexicanAmerican women. Arch Med Res. 2003;34(5):399-406.

47. Kayath M, Dib S, Vieira J. Prevalence and magnitude of osteopenia associated with insulin-dependent diabetes mellitus. J Diabetes Complicat. 1994;8(2):97-104.

48. Christensen J, Svendsen O. Bone mineral in pre and postmenopausal women with insulin-dependent and non-insulin-dependent diabetes mellitus. Osteoporos Int. 1999;10(4):307-311.

49. Phillips P, Braddon J. Osteoporosis - diagnosis, treatment and management. Aust Fam Physician. 2004;33(3):111-120.

50. Zylstra R, Porter L, Shapiro J, Prater C. Prevalence of osteoporosis in community-dwelling individuals with intellectual and/or developmental disabilities. J Am Med Dir Assoc. 2008;9(2):109-113.

51. Bonjour J, Chevalley T, Rizzoli R, Ferrari S. Gene-environment interactions in the skeletal response to nutrition and exercise during growth. Med Sport Sci. 2007;51(R):64-80.

52. Henry Y, Fatayerji D, Eastell R. Attainment of peak bone mass at the lumbar spine, femoral neck and radius in men and women: relative contributions of bone size and volumetric bone mineral density. Osteoporos Int. 2004;15(4):263-273.

53. Weaver C. The role of nutrition on optimizing peak bone mass. Asia Pac J Clin Nutr. 2008;17(Suppl 1):135-137.

54. Genant HK, Cooper C, Poor G, et al. Interim report and recommendations of the World Health Organization Task-Force for Osteoporosis. Osteoporos Int. 1999;10(4):259-264.

55. Cummings S, Bates D, Black D. Clinical use of bone densitometry: scientific review. JAMA. 2002;288(15):1889-1897.

56. Ross PD, Davis JW, Epstein RS, Wasnich RD. Pre-existing fractures and bone mass predict vertebral fracture incidence in women. Ann Intern Med. 1991;114(11):919-923.

57. Black DM, Arden NK, Palermo L, Pearson J, Cummings SR. Prevalent vertebral deformities predict hip fractures and new vertebral deformities but not wrist fractures. J Bone Miner Res. 1999;14(5):821-828.

58. Klotzbuecher CM, Ross PD, Landsman PB, Abbott TA 3rd, Berger M. Patients with prior fractures have an increased risk of future fractures: a summary of the literature and statistical synthesis. J Bone Miner Res. 2000;15(4):721-739.

59. Burger H, De Laet C, Weel A, Hofman A, Pols H. Added value of bone mineral density in hip fracture risk scores. Bone. 1999;25(3): 369-374.

60. Fowkes F. Aetiology of peripheral atherosclerosis. BMJ. 1989; 298(6671):405.

61. Slemenda CW, Hui SL, Longcope C, Johnston CC Jr. Cigarette smoking, obesity, and bone mass. J Bone Miner Res. 1989;4(5):737-741.

62. Ortego-Centeno N, Muñoz-Torres M, Hernandez-Quero J, Jurado-DuceA, de la Higuera Torres-Puchol J. Bone mineral density, sex steroids, and mineral metabolism in premenopausal smokers. Calcif Tissue Int. 1994;55(6):403-407. 
63. Nuti R, Martini G. Measurements of bone mineral density by DXA total body absorptiometry in different skeletal sites in postmenopausal osteoporosis. Bone. 1992;13(2):173-178.

64. Staa TP, Leufkens H, Cooper C. The epidemiology of corticosteroidinduced osteoporosis: a meta-analysis. Osteoporos Int. 2002;13(10): 777-787.

65. Cummings SR, Nevitt MC, Browner WS, et al. Risk factors for hip fracture in white women. $N$ Engl J Med. 1995;332(12):767-774.

66. Dargent-Molina P, Schott A, Hans D, et al. Separate and combined value of bone mass and gait speed measurements in screening for hip fracture risk: results from the EPIDOS study. Osteoporos Int. 1999; 9(2):188-192.

67. Garnero P, Hausherr E, Chapuy MC, et al. Markers of bone resorption predict hip fracture in elderly women: the EPIDOS Prospective Study. J Bone Miner Res. 1996;11(10):1531-1538.

68. Cummings SR, Browner WS, Bauer D, et al. Endogenous hormones and the risk of hip and vertebral fractures among older women. $N$ Engl J Med. 1998;339(11):733-738.

69. Nichols GA, Glauber HS, Brown JB. Type 2 diabetes: incremental medical care costs during the 8 years preceding diagnosis. Diabetes Care. 2000;23(11):1654-1659.

70. Arredondo A, Zúñiga A. Economic consequences of epidemiological changes in diabetes in middle-income countries. Diabetes Care. 2004; 27(1):104-109.

71. Seino Y, Ishida H. Diabetic osteopenia: pathophysiology and clinical aspects. Diabetes Metab Rev. 1995;11(1):21-35.

72. McNair P. Bone mineral metabolism in human type 1 (insulin dependent) diabetes mellitus. Dan Med Bull. 1988;35(2):109-121.

73. Weinstock R, Goland R, Shane E, Clemens T, Lindsay R, Bilezikian J. Bone mineral density in women with type II diabetes mellitus. $J$ Bone Miner Res. 1989;4(1):97-101.

74. Isaia G, Bodrato L, Carlevatto V, Mussetta M, Salamano G, Molinatti G. Osteoporosis in type II diabetes. Acta Diabetol. 1987;24(4):305-310.

75. Barrett-Connor E, Holbrook T. Sex differences in osteoporosis in older adults with non-insulin-dependent diabetes mellitus. JAMA. 1992; 268(23):3333-3337.

76. Ishida H, Seino Y, Matsukura S, Ikeda M. Diabetic osteopenia and circulating levels of vitamin D metabolites in type 2 (noninsulindependent) diabetes. Metabolism. 1985;34(9):797-801.

77. De Leeuw I, Abs R. Bone mass and bone density in maturity-type diabetics measured by the 125I photon-absorption technique. Diabetes. 1977;26(12):1130-1135.

78. Meema H, Meema S. The relationship of diabetes mellitus and body weight to osteoporosis in elderly females. Can Med Assoc J. 1967; 96(3):132-139.

79. Johnston C Jr, Hui S, Longcope C. Bone mass and sex steroid concentrations in postmenopausal Caucasian diabetics. Metabolism. 1985;34(6):544-550.

80. Bauer D, Browner W, Cauley J, et al. Factors associated with appendicular bone mass in older women. The Study of Osteoporotic Fractures Research Group. Ann Intern Med. 1993;118(9):657-665.

81. Isaia G, Ardissone P, Di Stefano M, et al. Bone metabolism in type 2 diabetes mellitus. Acta Diabetol. 1999;36(1):35-38.

82. Giacca A, Fassina A, Caviezel F, Cattaneo A, Caldirola G, Pozza G. Bone mineral density in diabetes mellitus. Bone. 1988;9(1):29-36.

83. Tuominen J, Impivaara O, Puukka P, Rönnemaa T. Bone mineral density in patients with type 1 and type 2 diabetes. Diabetes Care. 1999;22(7):1196-1200.

84. Sosa M, Dominguez M, Navarro M, et al. Bone mineral metabolism is normal in non-insulin-dependent diabetes mellitus. $J$ Diabetes Complicat. 1996;10(4):201-205.

85. AL-Elq A, Sadat-Ali M. Diabetes mellitus and male osteoporosis. Is there a relationship? Saudi Med J. 2006;27(11):1729-1733.

86. Izaolaa M, Escuderoe E, Herrerose V. Effects of dietary intake and life style on bone density in patients with diabetes mellitus type 2. Ann Nutr Metab. 2004;48:141-145.
87. Deutschmann H, Weger M, Weger W, Kotanko P, Deutschmann M, Skrabal F. Search for occult secondary osteoporosis: impact of identified possible risk factors on bone mineral density. J Intern Med. 2002; 252(5):389-397.

88. Lenchik L, Register T, Hsu F, et al. Adiponectin as a novel determinant of bone mineral density and visceral fat. Bone. 2003;33(4):646-651.

89. van Daele P, Stolk R, Burger H, et al. Bone density in non-insulindependent diabetes mellitus: the Rotterdam Study. Ann Intern Med. 1995;122(6):409-414.

90. Forsen L, Meyer H, Midthjell K, Edna T. Diabetes mellitus and the incidence of hip fracture: results from the Nord-Trøndelag Health Survey. Diabetologia. 1999;42(8):920-925.

91. Kwon D, Kim J, Chung K, Lee J, Kim S, Lee H. Bone mineral density of the spine using dual energy X-ray absorptiometry in patients with non-insulin-dependent diabetes mellitus. J Obstet Gynaecol Res. 1996; 22(2):157-162.

92. Heath H 3rd, Melton L 3rd, Chu C. Diabetes mellitus and risk of skeletal fracture. N Engl J Med. 1980;303(10):567-570.

93. Schwartz A, Sellmeyer D, Ensrud K, et al. Older women with diabetes have an increased risk of fracture: a prospective study. J Clin Endocrinol Metab. 2001;86(1):32-38.

94. Ottenbacher K, Ostir G, Peek M, Goodwin J, Markides K. Diabetes mellitus as a risk factor for hip fracture in Mexican American older adults. J Gerontol A Biol Sci Med Sci. 2002;57(10):M648-M653.

95. Ivers R, Cumming R, Mitchell P, Peduto A. Diabetes and risk of fracture. Diabetes Care. 2001;24(7):1198-1203.

96. Nicodemus K, Folsom A. Type 1 and type 2 diabetes and incident hip fractures in postmenopausal women. Diabetes Care. 2001;24(7): 1192-1197.

97. Hampson G, Evans C, Petitt R, et al. Bone mineral density, collagen type 1 alpha 1 genotypes and bone turnover in premenopausal women with diabetes mellitus. Diabetologia. 1998;41(11):1314-1320.

98. Seeman E. Osteoporosis in men: epidemiology, pathophysiology, and treatment possibilities. Am J Med. 1993;95(5):S22-S28.

99. Center J, Nguyen T, Schneider D, Sambrook P, Eisman J. Mortality after all major types of osteoporotic fracture in men and women: an observational study. Lancet. 1999;353(9156):878-882.

100. Jackson S, Tenenhouse A, Robertson L. Vertebral fracture definition from population-based data: preliminary results from the Canadian Multicenter Osteoporosis Study (CaMos). Osteoporos Int. 2000;11(8): 680-687.

101. Burger H, Van Daele P, Grashuis K, et al. Vertebral deformities and functional impairment in men and women. J Bone Miner Res. 1997; 12(1):152-157.

102. Takizawa M, Suzuki K, Matsubayashi T, et al. Increased bone resorption may play a crucial role in the occurrence of osteopenia in patients with type 2 diabetes: possible involvement of accelerated polyol pathway in its pathogenesis. Diabetes Res Clin Pract. 2008;82(1): 119-126.

103. Xu L, Cheng M, Liu X, Shan P, Gao H. Bone mineral density and its related factors in elderly male Chinese patients with type 2 diabetes. Arch Med Res. 2007;38(2):259-264.

104. Bridges M, Moochhala S, Barbour J, Kelly C. Influence of diabetes on peripheral bone mineral density in men: a controlled study. Acta Diabetol. 2005;42(2):82-86.

105. Noedin BEC, Need AG, Chatterton BE, Horowitz M, Morris HA. The relative contributions of age and years since menopause to postmenopausal bone loss. J Clin Endocrinol Metab. 1990;70(1):83-88.

106. Hadjidakis DJ, Kokkinakis EP, Sfakianakis ME, Raptis SA. Bone density patterns after normal and premature menopause. Maturitas. 2003;44(4):279-286.

107. Riggs BL, Khosla S, Melton LJ. Sex steroids and the construction and conservation of the adult skeleton. Endocr Rev. 2002;23(3): 279-302.

108. Moghimi N, Rahimi E, Derakhshan S, Farhadifar F. Osteoporosis in postmenopausal diabetic women; prevalence and related factors. Iran J Nucl Med. 2008;16(2):28-33. 
109. Al-Maatouq MA, El-Desouki MI, Othman SA, Mattar EH, Babay ZA, Addar M. Prevalence of osteoporosis among postmenopausal females with diabetes mellitus. Saudi Med J. 2004;25(10): $1423-1427$.

110. Anaforoglu I, Nar-Demirer A, Bascil-Tutuncu N, Ertorer M. Prevalence of osteoporosis and factors affecting bone mineral density among postmenopausal Turkish women with type 2 diabetes. J Diabetes Complicat. 2009;23(1):12-17.

111. Krakauer J, McKenna M, Buderer N, Rao D, Whitehouse F, Parfitt A. Bone loss and bone turnover in diabetes. Diabetes. 1995;44(7): 775-782.

112. Okazaki R, Totsuka Y, Hamano K, et al. Metabolic improvement of poorly controlled noninsulin-dependent diabetes mellitus decreases bone turnover. J Clin Endocrinol Metab. 1997;82(9):2915-2920.

113. Haffner $S$, Bauer R. The association of obesity and glucose and insulin concentrations with bone density in premenopausal and postmenopausal women. Metabolism. 1993;42(6):735-738.

114. Reid I, Evans M, Cooper G, Ames R, Stapleton J. Circulating insulin levels are related to bone density in normal postmenopausal women. Am J Physiol Endocrinol Metab. 1993;265(4):E655.

115. Stolk R, Van Daele P, Pols H, et al. Hyperinsulinemia and bone mineral density in an elderly population: the Rotterdam Study. Bone. 1996; 18(6):545-549.

116. Barrett-Connor E, Kritz-Silverstein D. Does hyperinsulinemia preserve bone? Diabetes Care. 1996;19(12):1388-1392.

117. Majima T, Komatsu Y, Yamada T, et al. Decreased bone mineral density at the distal radius, but not at the lumbar spine or the femoral neck, in Japanese type 2 diabetic patients. Osteoporos Int. 2005;16(8): 907-913.

118. Akanuma Y. Non-insulin-dependent diabetes mellitus (NIDDM) in Japan. Diabet Med. 1996;13(9 Suppl 6):S11-S12.

119. Yoshinaga H, Kosaka K. Heterogeneous relationship of early insulin response and fasting insulin level with development of non-insulindependent diabetes mellitus in non-diabetic Japanese subjects with or without obesity. Diabetes Res Clin Pract. 1999;44(2): 129-136.

120. Oz S, Guven G, Kilicarslan A, Calik N, Beyazit Y, Sozen T. Evaluation of bone metabolism and bone mass in patients with type-2 diabetes mellitus. J Natl Med Assoc. 2006;98(10):1598-1604.

121. Hawker G, Jamal S, Ridout R, Chase C. A clinical prediction rule to identify premenopausal women with low bone mass. Osteoporos Int 2002;13(5):400-406.

122. Ho A, Kung A. Determinants of peak bone mineral density and bone area in young women. $J$ Bone Miner Metab. 2005;23(6):470-475.

123. Espallargues M, Sampietro-Colom L, Estrada M, et al. Identifying bone-mass-related risk factors for fracture to guide bone densitometry measurements: a systematic review of the literature. Osteoporos Int. 2001;12(10):811-822.

124. Vestergaard P. Discrepancies in bone mineral density and fracture risk in patients with type 1 and type 2 diabetes - a meta-analysis. Osteoporos Int. 2007;18(4):427-444.

125. Wang M, Bachrach L, Van Loan M, Hudes M, Flegal K, Crawford P. The relative contributions of lean tissue mass and fat mass to bone density in young women. Bone. 2005;37(4):474-481.

126. Barrera G, Bunout D, Gattás V, de la Maza M, Leiva L, Hirsch S. A high body mass index protects against femoral neck osteoporosis in healthy elderly subjects. Nutrition. 2004;20(9):769-771.

127. Lauderdale D, Rathouz P. Body mass index in a US national sample of Asian Americans: effects of nativity, years since immigration and socioeconomic status. Int J Obes. 2000;24(9):1188-1194.

128. Torréns J, Skurnick J, Davidow A, et al. Ethnic differences in insulin sensitivity and beta-cell function in premenopausal or early perimenopausal women without diabetes. Diabetes Care. 2004;27(2):354-361.

129. Ford ES, Williamson DF, Liu S. Weight change and diabetes incidence: findings from a national cohort of US adults. Am J Epidemiol. 1997;146(3):214-222.
130. Asomaning K, Bertone-Johnson ER, Nasca PC, Hooven F, Pekow PS. The association between body mass index and osteoporosis in patients referred for a bone mineral density examination. $J$ Womens Health (Larchmt). 2006;15(9):1028-1034.

131. Hedley AA, Ogden CL, Johnson CL, Carroll MD, Curtin LR, Flegal KM. Prevalence of overweight and obesity among US children, adolescents, and adults, 1999-2002. JAMA. 2004;291(23):2847-2850.

132. Okosun IS, Choi S, Matamoros T, Dever G. Obesity is associated with reduced self-rated general health status: evidence from a representative sample of white, black, and Hispanic Americans. Prev Med. 2001; 32(5):429-436.

133. Flegal KM, Carroll MD, Ogden CL, Johnson CL. Prevalence and trends in obesity among US adults, 1999-2000. JAMA. 2002;288(14): 1723-1727.

134. Baltrus PT, Lynch JW, Everson-Rose S, Raghunathan TE, Kaplan GA. Race/ethnicity, life-course socioeconomic position, and body weight trajectories over 34 years: the Alameda County Study. Am J Public Health. 2005;95(9):1595-1601.

135. He XZ, Baker DW. Body mass index, physical activity, and the risk of decline in overall health and physical functioning in late middle age. Am J Public Health. 2004;94(9):1567-1573.

136. Kahn HS, Williamson DF. Is race associated with weight change in US adults after adjustment for income, education, and marital factors? Am J Clin Nutr. 1991;53(6):1566S-1570S.

137. Paeratakul S, Lovejoy J, Ryan D, Bray G. The relation of gender, race and socioeconomic status to obesity and obesity comorbidities in a sample of US adults. Int J Obes. 2002;26(9):1205-1210.

138. Seo DC, Torabi MR. Racial/ethnic differences in body mass index, morbidity and attitudes toward obesity among US adults. $J$ Natl Med Assoc. 2006;98(8):1300-1308.

139. Kuczmarski RJ, Flegal KM, Campbell SM, Johnson CL. Increasing prevalence of overweight among US adults. JAMA. 1994;272(3):205-211.

140. Ko G, Chan J, Woo J, et al. Simple anthropometric indexes and cardiovascular risk factors in Chinese. Int J Obes. 1997;21(11):995-1001.

141. Millar WJ, Stephens T. The prevalence of overweight and obesity in Britain, Canada, and United States. Am J Public Health. 1987;77(1): $38-41$.

142. Reeder BA, Angel A, Ledoux M, Rabkin SW, Young TK, Sweet L. Obesity and its relation to cardiovascular disease risk factors in Canadian adults. Canadian Heart Health Surveys Research Group. CMAJ. 1992;146(11):2009-2019.

143. Lean M, Han T, Morrison C. Waist circumference as a measure for indicating need for weight management. BMJ. 1995;311(6998): 158-161.

144. Hsu Y, Chen C, Feng F, et al. Major determinants of bone mineral density (BMD) at multiple skeletal sites in Chinese. J Bone Miner. Res. 2004;19:S421

145. Deurenberg P, Yap M, van Staveren WA. Body mass index and percent body fat: a meta analysis among different ethnic groups. Int $J$ Obes. 1998;22(12):1164-1171.

146. Novotny R, Davis J, Ross P, Wasnich R. Adiposity and blood pressure in a multiethnic population of women in Hawaii. Ethn Health. 1998; 3(3):167-173.

147. Rosen CJ, Bouxsein ML. Mechanisms of disease: is osteoporosis the obesity of bone? Nat Clin Pract Rheumatol. 2006;2(1):35-43.

148. Wehrli FW, Hopkins JA, Hwang SN, Song HK, Snyder PJ, Haddad JG. Cross-sectional study of osteopenia with quantitative MR imaging and bone densitometry. Radiology. 2000;217(2): 527-538.

149. Rishaug U, Birkeland K, Falch J, Vaaler S. Bone mass in non-insulindependent diabetes mellitus. Scand J Clin Lab Investig. 1995; 55(3):257-262.

150. El Miedany Y, El Gaafary S, El Baddini M. Osteoporosis in older adults with non-insulin-dependent diabetes mellitus: is it sex related? Clin Exp Rheumatol. 1999;17(5):561-567. 
151. Sahin G, Bağis S, Cimen OB, Ozişik S, Güler H, Erdoğan C. Lumbar and femoral bone mineral density in type 2 Turkish diabetic patients. Acta Medica (Hradec Kralove). 2001;44(4):141-143.

152. Sert M, Tetiker T, Kirim S, Soyupak S, Canataroğlu A, Koçak M. Type 2 diabetes mellitus and osteopenia: is there an association? Acta Diabetol. 2003;40(2):105-108.

153. Strotmeyer ES, Cauley JA, Schwartz AV, et al. Diabetes is associated independently of body composition with BMD and bone volume in older white and black men and women: the Health, Aging, and Body Composition Study. J Bone Miner Res. 2004;19(7):1084-1091.

154. Pérez-Castrillón J, De Luis D, Martín-Escudero J, Asensio T, del Amo R, Izaola O. Non-insulin-dependent diabetes, bone mineral density, and cardiovascular risk factors. J Diabetes Complicat. 2004; 18(6):317-321.

155. Dennison E, Syddall H, Aihie Sayer A, Craighead S, Phillips D, Cooper C. Type 2 diabetes mellitus is associated with increased axial bone density in men and women from the Hertfordshire Cohort Study: evidence for an indirect effect of insulin resistance? Diabetologia. 2004;47(11):1963-1968.

156. Hossein-Nezhad A, Larijani B, Pajouhi M, Adibi H. Type 2 diabetes mellitus and the effects of lifestyle on bone mineral density in pre- and postmenopausal women. Iran J Diabetes Lipid Dis. 2004; 3(1):13-21.

157. De Liefde I, Van der Klift M, de Laet C, van Daele P, Hofman A, Pols H. Bone mineral density and fracture risk in type-2 diabetes mellitus: the Rotterdam Study. Osteoporos Int. 2005;16(12): 1713-1720.

158. Gerdhem P, Isaksson A, Åkesson K, Obrant KJ. Increased bone density and decreased bone turnover, but no evident alteration of fracture susceptibility in elderly women with diabetes mellitus. Osteoporos Int. 2005;16(12):1506-1512.
159. Sharifi F, Moghaddam NA, Mousavi-Nasab N. The effects of type ii diabetes on bone density in menopause women. Iran J Diabetes Lipid Dis. 2005;5(2):135-142. Persian.

160. Maghbooli Z, Hossein-nezhad A, Khoshniat M, Adibi H, Mohammadzadeh N, Larijani B. A study of bone mineral density in diabetes mellitus patients. Iran J Public Health. 2007:37-44.

161. Broussard D, Magnus J. Influence of cardiovascular disease risk factors on the relationship between low bone mineral density and type 2 diabetes mellitus in a multiethnic US population of women and men: a cross-sectional study. Gend Med. 2008;5(3):229-238.

162. Al-Zaabi K, Badr HE, Mahussain S, Mohammad M, Al-Nafisi N, Badr HES. Bone mass density in diabetic women: is there a detrimental effect? Middle East J Age Aging. 2008;5(2):12-17.

163. Hadzibegovic I, Miskic B, Cosic V, Prvulovic D, Bistrovic D. Increased bone mineral density in postmenopausal women with type 2 diabetes mellitus. Ann Saudi Med. 2008;28(2):102-104.

164. Hosoda H, Fukui M, Nakayama I, et al. Bone mass and bone resorption in postmenopausal women with type 2 diabetes mellitus. Metabolism. 2008;57(7):940-945.

165. Gupta R, Mohammed AM, Mojiminiyi OA, Alenizi EK, Abdulla NA. Bone mineral density in premenopausal Arab women with type 2 diabetes mellitus. J Clin Densitom. 2009;12(1):54-57.

166. Shan $\mathrm{P}, \mathrm{Wu} \mathrm{X}, \mathrm{Zhang} \mathrm{H}$, et al. Bone mineral density and its relationship with body mass index in postmenopausal women with type 2 diabetes mellitus in mainland China. J Bone Miner Metab. 2009; 27(2):190-197.

167. Zhou Y, Li Y, Zhang D, Wang J, Yang H. Prevalence and predictors of osteopenia and osteoporosis in postmenopausal Chinese women with type 2 diabetes. Diabetes Res Clin Pract. 2010;90(3):261-269.
Patient Preference and Adherence

\section{Publish your work in this journal}

Patient Preference and Adherence is an international, peer-reviewed, open access journal focusing on the growing importance of patient preference and adherence throughout the therapeutic continuum. Patient satisfaction, acceptability, quality of life, compliance, persistence and their role in developing new therapeutic modalities and compounds to

\section{Dovepress}

optimize clinical outcomes for existing disease states are major areas of interest. This journal has been accepted for indexing on PubMed Central. The manuscript management system is completely online and includes a very quick and fair peer-review system. Visit http://www.dovepress.com/ testimonials.php to read real quotes from published authors. 